\title{
THE EFFECT OF MULTIPHASE NUTRITION ON PRODUCTION PERFORMANCES OF BROILERS
}

\author{
N. Tolimir ${ }^{1}$, L. Perić ${ }^{2}$, N. Milošević ${ }^{2}$, V. Bogdanović ${ }^{3}$ \\ ${ }^{1}$ Institute of Science Application in Agriculture, Bulevar Despota Stefana 68b, 11000, Belgrade, \\ Republic of Serbia \\ ${ }^{2}$ Faculty of Agriculture, Novi Sad, Trg Dositeja Obradovića 8, 21000, Novi Sad, Republic of Serbia \\ ${ }^{3}$ Faculty of Agriculture, Nemanjina 6,11080, Belgrade-Zemun, Republic of Serbia \\ Corresponding author: ntolimir@ipn.co.rs \\ Original scientific paper
}

\begin{abstract}
Multiphase broiler nutrition is important from the standpoint of nutrition optimization, economical efficiency of production and protection of the environment. Objective of research is to investigate the effect of multiphase nutiriton, i.e. different mixtures used in broiler nutrition, whse protein content has been reduced in several phases during first fattening stage, on production performances of broilers. Investigation was carried out on 608 individually tagged male chickens, Ross 308 strain, divided into 4 groups: T1 (control group) nutrition with mixture containing $23 \%$ of protein from $1-21^{\text {st }}$ day; $\mathrm{T} 2$ - nutrition with mixture containing $23 \%$ of protein from $1^{\text {st }}$ to $7^{\text {th }}$ day, and from $7^{\text {th }}$ to $21^{\text {st }}$ day diet containing $21.5 \%$ protein; T3 - nutrition with mixture containing $23 \%$ of protein from $1^{\text {st }}$ to $14^{\text {th }}$ day and from $14^{\text {th }}$ to $21^{\text {st }}$ day diet containing $21.5 \%$ protein and T4 - nutrition with mixture containing $23 \%$ of protein from $1^{\text {st }}$ to $3^{\text {rd }}$ day, from $4-6^{\text {th }}$ day with $22.55 \%$ protein, $7-9^{\text {th }}$ day with $22.10 \%$ protein, $10-12^{\text {th }}$ day diet with $21.65 \%$ protein, $13-15^{\text {th }}$ day with $21.20 \%$ protein, $16-18^{\text {th }}$ day with $20.75 \%$ protein and $19^{\text {th }}-21^{\text {st }}$ day diet with $20.30 \%$ protein. Main production parameters were registered during the trial period (from 1 to $21^{\text {st }}$ day). Through processing of obtained data it ewas established that chickens of the T4 group $(2092.42 \mathrm{~g})$, had realized statistically significantly higher body mass compared to T2 $(2025.00 \mathrm{~g})$ and T3 $(2020.07 \mathrm{~g})$, but not in relation to control group T1 (2055.16g), during trial period of 42 days. Also, it can be concluded that in regard to daily gain in period up to 21 st day, no statistically significant differences between trial groups were established, however, for the entire trial period, average daily gain of chickens in T4 group (48.84g) was statistically considerably higher compared to T2 (47.24g) and T3 (47.13g), whereas in relation to T1 no differences were established T1 (47.99). Feed conversion differed between groups, precisely in favor of the application of multiphase broiler nutrition, i.e. feed conversion of the trial group T4 (1.870) was the best compared to T1 (1.918), T2 (2.005) and T3 (1.970). Based on obtained results it can be concluded that multiphase nutrition had effect on production performances, primarily level of food utilization.
\end{abstract}

Key words: broiler, sex, multiphase nutrition, production traits 


\section{Introduction}

Multiphase broiler nutrition, in function of nutrition optimization, economical efficiency of production and protection of environment, is increasingly gaining interest. Multiphase nutrition is based on fullfiling of nutritious requirements og broilers in specific moments of their life cycle, for the purpose of nutrition oprimization, i.e. "fitting" of feed components to broiler needs in certain growth stages.

Nutritionists aspire towards maximum adjustment of the intake of nutritious substances by chickens in growth to their biological requirements, which is not easy to do in practice, considering that requirements of the chickens vary under the influence of various factors, and also specific differences at the level of genotype are apperent. Indicating the problem of precision in deifning of the requirements (Ferket et al., 2002) stated that nutrition requirements are like "moving targets", pointing out considerable genetic variations in growth characteristics, especially in regard to protein retention.

In regard to different broiler fattening periods, to early fattening period special attention is paid, and nutrition in the starter period is considered critical for achievment of ptimal production performances and therefore topic of research by numerous authors (Baker and Han, 1994; Teimovri et al., 2005; Gomes et al., 2006). Studies indicated that the broiler requirements in proteins and amino acids change with the age, and that utilization of one diet over longer period of time resulted in suficit or deficit of nutrients in main part of the growth period. In regard to stated, Belyavinu (1999) suggested that during growth period more different diets are given to birds, i.e. that the broiler nutrition be based on program of multiphase nutrition. Research indicates that mixtures with reduced protein content had no efect on body mass and consumption of food by broilers, but the effect on economical efficiency of fattening was significant (Saleh et al., 1996; Warren and Emmert, 2000).

Objective of the study was to investigate the effect of several programs of multiphase nutrition, i.e. effect of different mixtures used in broiler nutrition where protein content had been reduced in several phases during the first fattening period, on production traits of fattening chickens.

\section{Materials and Methods}

Trial was carried out on experimental farm of the Faculty of Agriculture, Novi Sad, in Temering. Study was performed on 608 individually tagged male chickens, of Ross 308 strain. Chickens were housed in 16 boxes, 38 chickens in 
each box (i.e. four boxes per treatment), divided according to random block system. Standard fattening technology was applied, in duration of 42 days. Nutrition of chickens was ad libitum, with four nutrition treatments:

T1 (control group) - nutrition with mixture containing $23 \%$ of protein from $1^{\text {st }}$ to $21^{\text {st }}$ day; T2 - nutrition with mixture containing $23 \%$ of protein from $1^{\text {st }}$ to $7^{\text {th }}$ day, and from $7^{\text {th }}$ to $21^{\text {st }}$ day diet containing $21.5 \%$ protein; T3 - nutrition with mixture containing $23 \%$ of protein from $1^{\text {st }}$ to $14^{\text {th }}$ day and from $14^{\text {th }}$ to $21^{\text {st }}$ day diet containing $21.5 \%$ protein and T4 - nutrition with mixture containing $23 \%$ of protein from $1^{\text {st }}$ to $3^{\text {rd }}$ day, from $4^{\text {th }}-6^{\text {th }}$ day with $22.55 \%$ protein, $7^{\text {th }}-9^{\text {th }}$ day with $22.10 \%$ protein, $10^{\text {th }}-12^{\text {th }}$ day diet with $21.65 \%$ protein, $13^{\text {th }}-15^{\text {th }}$ day with $21.20 \%$ protein, $16^{\text {th }}-18^{\text {th }}$ day with $20.75 \%$ protein and $19^{\text {th }}-21^{\text {st }}$ day diet with $20.30 \%$ protein.

Diet based on maize-soybean was used, and multiphase mixtures for nutrition of chickens were obtained by mixing of two basic diets, i.e. fist mixture containing $23 \%$ of proteins and $13 \mathrm{MJ} / \mathrm{kg}$ of metabolic energy and the second diet with $20 \%$ of protein and $13.3 \mathrm{MJ} / \mathrm{kg}$ of metabolic energy. Treatments differed in regard to level of protein, but also other nutrients, depending on the proportional share of two basic diets, whose ratio changed according to said program of nutrition.

After $21^{\text {st }}$ day, all chickens were fed the same way, i.e. in the period from $21^{\text {st }}$ to $35^{\text {th }}$ day, diet containing $20 \%$ of protein and in the period from $35^{\text {th }}$ to $42^{\text {nd }}$ day of fattening diet containing $18 \%$ of protein.

During trial period control of body mass was done by individual weighing of all chickens on the first day, and weekly from the $1^{\text {st }}$ to $6^{\text {th }}$ week of age. Based on differences in body mass of chickens, established in weekly measuring of birds, data dor weekly and daily gain were calculated. Feed conversion was calculated based on data on food consumption and gain of chickens for each box, in certain phases and at the end of trial, and also all dead chickens were included into calculation. Data was calculated for weekly and daily gain and feed conversion.

Computer program STATISTIKA, ANOVA MANOVA and LSD post-hoc test were used for processing of data.

\section{Results and Discussion}

In Table 1 the significance of differences in body masses, per weeks, are presented. 
Table 1. Significance of differences in body masses, per weeks

\begin{tabular}{|c|c|c|c|c|c|c|c|c|}
\hline \multirow{2}{*}{ Treatment } & \multicolumn{9}{|c|}{ Body mass, g } \\
\cline { 2 - 9 } Week & \multicolumn{2}{|c|}{1} & \multicolumn{2}{|c|}{2} & \multicolumn{2}{c|}{3} & \multicolumn{2}{c|}{4} \\
\hline & $\bar{x}$ & $\mathrm{Sd}$ & $\bar{x}$ & $\mathrm{Sd}$ & $\bar{x}$ & $\mathrm{Sd}$ & $\bar{x}$ & $\mathrm{Sd}$ \\
\hline 1 & $138.14^{\mathrm{a}}$ & 14.91 & $137.40^{\mathrm{a}}$ & 15.84 & $137.75^{\mathrm{a}}$ & 15.81 & $133.56^{\mathrm{b}}$ & 14.96 \\
\hline 2 & $361.29^{\mathrm{a}}$ & 41.89 & $354.83^{\mathrm{a}}$ & 38.25 & $356.65^{\mathrm{a}}$ & 44.49 & $340.08^{\mathrm{b}}$ & 46.52 \\
\hline 3 & $723.48^{\mathrm{a}}$ & 82.41 & $714.54^{\mathrm{a}}$ & 69.76 & $724.86^{\mathrm{a}}$ & 84.16 & $705.63^{\mathrm{a}}$ & 88.60 \\
\hline 4 & $1142.45^{\mathrm{a}}$ & 132.09 & $1130.80^{\mathrm{a}}$ & 127.70 & $1158.48^{\mathrm{a}}$ & 144.32 & $1064.34^{\mathrm{a}}$ & 143.90 \\
\hline 5 & $1607.42^{\mathrm{ab}}$ & 157.91 & $1594.96^{\mathrm{ab}}$ & 160.64 & $1572.13^{\mathrm{b}}$ & 167.10 & $1620.72^{\mathrm{a}}$ & 174.20 \\
\hline 6 & $2055.16^{\mathrm{ab}}$ & 173.15 & $2025.00^{\mathrm{b}}$ & 190.07 & $2020.07^{\mathrm{b}}$ & 199.57 & $2092.42^{\mathrm{a}}$ & 208.55 \\
\hline
\end{tabular}

${ }^{\mathrm{a}-\mathrm{b}}$ Values within a row without same superscript are statistically significantly different $(\mathrm{P}<0.05)$

It can be observed from Table 1 that during the first fattening period, chickens T1 (138.14 g; $361.29 \mathrm{~g}), \mathrm{T} 2(137.40 \mathrm{~g} ; 354.83 \mathrm{~g})$ and T3 (137.75 g; $356.65 \mathrm{~g})$ realized in first two weeks statistically significantly greaterbody mass compared to chickens of group T4 $(133.56 \mathrm{~g} ; 340.08 \mathrm{~g})$. however, in the third week of fattening, the difference in body mass between chickens of group T4 and other groups diminished, so that by the end of the starter period $\left(21^{\text {st }}\right.$ day) it wasn't statistically significant. Obtained results, according to which reduction of protein in food resulted in decrease of body mass in the first fattening period are in accordance to results obtained by Reazeia et al. (2006) and Gomes et al. (2006). In the research by same authors, at the end of the trial period it was established that

At the end of the trial period, at the age of 42 days, group T4 (2092.42 g) had ralized statistically significantly higher body mass compared to T2 (2025.00 g) and T3 (2020.07 g), but not compared to control T1 group (2055.16 g), which can be brought in connection to study of Warren and Emmert (2000) who established that multiphase nutrition had no effect on body mass of chickens.

In Table 2 the significance of differences in daily gain per weeks is presented.

Table 2. Significance of differences in daily gain, per weeks

\begin{tabular}{|c|c|c|c|c|c|c|c|c|}
\hline \multirow{2}{*}{ Week Treatment } & \multicolumn{9}{|c|}{ Daily gain, $\mathrm{g}$} \\
\cline { 2 - 9 } & \multicolumn{2}{|c|}{1} & \multicolumn{2}{|c|}{2} & \multicolumn{2}{c|}{3} & \multicolumn{2}{c|}{4} \\
\cline { 2 - 9 } & $\bar{x}$ & $\mathrm{Sd}$ & $\bar{x}$ & $\mathrm{Sd}$ & $\bar{x}$ & $\mathrm{Sd}$ & $\bar{x}$ & $\mathrm{Sd}$ \\
\hline 1 & $14.05^{\mathrm{a}}$ & 2.11 & $13.81^{\mathrm{a}}$ & 2.11 & $13.84^{\mathrm{a}}$ & 2.21 & $13.20^{\mathrm{b}}$ & 2.04 \\
\hline 2 & $32.39^{\mathrm{a}}$ & 5.54 & $31.20^{\mathrm{a}}$ & 4.31 & $31.26^{\mathrm{ab}}$ & 5.56 & $30.08^{\mathrm{b}}$ & $5 . .44$ \\
\hline 3 & $52.10^{\mathrm{a}}$ & 9.19 & $51.09^{\mathrm{a}}$ & 7.03 & $52.53^{\mathrm{a}}$ & 7.52 & $51.92^{\mathrm{a}}$ & 7.91 \\
\hline 4 & $59.76^{\mathrm{a}}$ & 12.63 & $61.77^{\mathrm{a}}$ & 14.80 & $61.11^{\mathrm{a}}$ & 11.75 & $61.09^{\mathrm{a}}$ & 10.41 \\
\hline 5 & $66.44^{\mathrm{a}}$ & 12.84 & $67.20^{\mathrm{a}}$ & 12.07 & $60.23^{\mathrm{b}}$ & 12.88 & $69.38^{\mathrm{a}}$ & 10.45 \\
\hline 6 & $64.05^{\mathrm{a}}$ & 11.60 & $62.08^{\mathrm{a}}$ & 13.15 & $63.99^{\mathrm{a}}$ & 13.11 & $67.69^{\mathrm{b}}$ & 13.88 \\
\hline
\end{tabular}

${ }^{\mathrm{a}-\mathrm{b}}$ Values within a row without same superscript are statistically significantly different $(\mathrm{P}<0.05)$ 
It can be observed (Table 2) that in the first and the second week daily gain of chickens from the trial T4 group $(13.20 ; 30.08)$ which consumed food with lower protein content was statistically significantly lower compared to other three trial groups. However, in third and fourth week, no statistically significant differences between trial groups were established, and at the end of trial period, in the fifth and sixth week, the highest gain was established in group T4, which was statistically significantly higher compared to $\mathrm{T} 2$ and $\mathrm{T} 3$ group.

Table 3. Significance of differences in daily gains in certain fattening periods

\begin{tabular}{|c|c|c|c|c|c|c|c|c|}
\hline \multirow{2}{*}{ Treatment } & \multicolumn{9}{|c|}{ Daily gain, $\mathrm{g}$} \\
\cline { 2 - 10 } & \multicolumn{2}{|c|}{1} & \multicolumn{2}{|c|}{2} & \multicolumn{2}{c|}{3} \\
\cline { 2 - 9 } & $\bar{x}$ & $\mathrm{Sd}$ & $\bar{x}$ & $\mathrm{Sd}$ & $\bar{x}$ & $\mathrm{Sd}$ & $\bar{x}$ & $\mathrm{Sd}$ \\
\hline $1-21$ & $32.56^{\mathrm{a}}$ & 7.69 & $32.10^{\mathrm{a}}$ & 6.47 & $32.57^{\mathrm{a}}$ & 7.84 & $31.64^{\mathrm{a}}$ & 8.28 \\
\hline $21-42$ & $64.16^{\mathrm{b}}$ & 10.83 & $64.82^{\mathrm{ab}}$ & 13.16 & $62.14^{\mathrm{bc}}$ & 11.33 & $66.21^{\mathrm{a}}$ & 10.77 \\
\hline $1-42$ & $47.99^{\mathrm{ab}}$ & 4.61 & $47.24^{\mathrm{b}}$ & 5.12 & $47.13^{\mathrm{b}}$ & 5.20 & $48.84^{\mathrm{a}}$ & 5.35 \\
\hline
\end{tabular}

${ }^{\mathrm{a}-\mathrm{b}}$ Values within a row without same superscript are statistically significantly different $(\mathrm{P}<0.05)$

Daily gain per periods is presented in Table 3 , and based on data it can be observed that in the first fattening period, to $21^{\text {st }}$ day, the lowest daily gain was realized by chickens of trial group $\mathrm{T} 4$, even though no statistically significant differences between groups were established, which is in accordance to research of Nasil (2003), for the same study period. However, in the second fatening period, and also from the standpoint of view of entire trial period, the highest gain was realized by group T4 $(66.21 \mathrm{~g} ; 48.84 \mathrm{~g})$.

Table 4. Significance of differences in conversion of diets in certain fattening periods

\begin{tabular}{|c|c|c|c|c|}
\hline \multirow{2}{*}{ Tretment } & \multicolumn{4}{|c|}{ Feed conversion } \\
\cline { 2 - 5 } Period (days) & 1 & 2 & 3 & 4 \\
\hline $1-21$ & $1.530^{\mathrm{a} b}$ & $1.645^{\mathrm{b}}$ & $1.573^{\mathrm{a}}$ & $1.468^{\mathrm{a}}$ \\
\hline $21-35$ & $1.902^{\mathrm{a}}$ & $2.076^{\mathrm{a}}$ & $2.107^{\mathrm{a}}$ & $1.939^{\mathrm{a}}$ \\
\hline $35-42$ & $2.387^{\mathrm{a}}$ & $2.444^{\mathrm{a}}$ & $2.428^{\mathrm{a}}$ & $2.327^{\mathrm{a}}$ \\
\hline $1-42$ & $1.918^{\mathrm{ab}}$ & $2.005^{\mathrm{a}}$ & $1.970^{\mathrm{a}}$ & $1.870^{\mathrm{b}}$ \\
\hline
\end{tabular}

${ }^{-b}$ Values within a row without same superscript are statistically significantly different $(\mathrm{P}<0.05)$

Feed conversion differed between groups, in favor of application of multiphase broiler nutrition. Namely, feed conversion in trial group T4 (1.468) was the most favourable compared to T1 (1.530), T2 (1.645) and T3 (1.573) during starter period, which is in accordance to study of the program of multiphase nutrition of Rezaeia et al. (2006). In the peiod from fourth to sixth week, when trial groups consumed same food, no statistically significant differences between groups were established, however, at the level of entire trial period, trial group T4 (1.870) had the best feed conversion. 
Programs of multiphase nutrition had no effect on mortality, i.e. mortality of all trial groups was within the allowed limits stated in the technology (to 5\%), and obtained values for all four groups showed no statistically significant differences.

\title{
Conclusion
}

Multiphase nutrition included application of several mixtures during fattening, with aim to adjust in the best possible way the composition of food to requirements of broilr chickens and in this way improve the utilization of food, i.e. increase the economical efficiency of production.

Based on obtained results it can be concluded that applied programs of multiphase nutrition have resulted in different influences on production performances. Program of multiphase nutrition (T4), where protein content had been reduced in several phases, realized the highest final body mass of broilers, the best gain and best feed conversion. Positive effect of this program of nutrition was exhibited primarily on the level of food utilization, which is in favor of application of multiphase nutrition, considering that the difference in conversion can be essential for realization of positive economical result in production. Also, it can be concluded that in the study of multiphase nutrition, not the effects, i.e. the influence on production performance based on starter period, should be considered, but at the end of fattening period.

\section{Acknowledgment}

Study is financed by the Ministry of Science and Technological Development of Republic of Serbia, Project TR-20021.

\section{Uticaj multifazne ishrane na proizvodne performanse brojlera}

\author{
N. Tolimir, L. Perić, N. Milošević, V. Bogdanović
}

\section{Rezime}

Multifazna ishrana brojlera je značajna sa aspekta optimiziranja ishrane, ekonomičnosti proizvodnje i zaštite životne sredine. Cilj istraživanja je da se ispita uticaj multifazne ishrane, odnosno različitih smeša za ishranu brojlera, u kojima je 
sadržaj proteina smanjen višefazno u prvoj fazi tova, na proizvodne osobine tovnih pilića.

Ispitivanje je izvedeno na 608 individualno obeleženih pilića muškog pola, provenijence Ross 308, podeljenih u četiri grupe: T1 (kontrolna grupa) - ishrana smešom sa $23 \%$ proteina u trajanju od 1-21 dana; T2 - ishrana od 1-7 dana smešom sa $23 \%$ proteina i od $7-21$ dana sa $21,5 \%$ proteina; T3 - ishrana od 1-14 dana smešom sa $23 \%$ proteina i od $14-21$ dana sa $21,5 \%$ proteina i T4 - ishrana 1 3 dana smešom sa $23 \%$ proteina, $4-6$ dana sa $22,55 \%$ proteina, $7-9$ dana sa $22,10 \%$ proteina, $10-12$ dana sa $21,65 \%$ proteina, $13-15$ dana sa $21,20 \%$ proteina, $16-18$ dana sa $20,75 \%$ proteina i $19-21$ dana sa $20,30 \%$ proteina. U oglednom periodu (od 1-42 dana) praćeni su osnovni proizvodni parametri.

Obradom podataka utvrđeno je da su pilići T4 grupe $(2092,42 \mathrm{~g})$, ostvarili statistički značajno veću telesnu masu u odnosu na T2 $(2025,00 \mathrm{~g})$ i T3 $(2020,07 \mathrm{~g})$, ali ne i u odnosu na kontrolnu T1 grupu $(2055,16 \mathrm{~g})$, u oglednom periodu od 42 dana. Takođe se može konstatovati da za dnevni prirast u periodu do 21. dana nisu utvrđene statistički značajne razlike između oglednih grupa, međutim posmatrano za ceo ogledni period, prosečan dnevni prirast T4 grupe $(48,84 \mathrm{~g})$ bio je statistički značajno veći u poređenju sa T2 $(47,24 \mathrm{~g})$ i T3 $(47,13 \mathrm{~g})$, dok nije bilo razlika u poređenju sa T1 $(47,99)$ oglednom grupom. Konverzija hrane razlikovala se između grupa, upravo na način koji govori u prilog primeni multifazne ishrane brojlera, odnosno konverzija ogledne T4 grupe $(1,870)$ bila je najpovoljnija u poređenju sa T1 $(1,918), \mathrm{T} 2(2,005)$ i T3 $(1,970)$. Na osnovu dobijenih rezultata može se zaključiti da je multifazna ishrana imala uticaj na proizvodne performanse, a prevashodno na stepen iskorišćavanja hrane.

\section{References}

BAKER D.H., HAN Y. (1994): Ideal amino acid profile for chicks during the first three weeks post hatching. Poult. Sci., 73, 1441-1447.

BELYAVIN C.G. (1999): Nutrition management of broiler programs. Pages 93105 in ances in Animal Nutrition. Nottingham University Press, Nottingham, Recent Adv UK.

FERKET P.R., VAN HEUGTEN E., VAN KEMPEN T.A., ANGEL D.R. (2002): Nutritional strategies to reduce environmental emissions from nonruminants. J. Anim. Sci., 80, 168-182.

GOMES G.A, ARAUJO L.F., PREZZI J.A., BARBOSA L.C.G.S., SAVIETTO D., CREN FILHO A.W. (2006): Period of feeding a pre starter diet on performance up to 42 days of broilers of different body weights at housing. book of Abstrats, XII European Poultry Conference, Italy, 298-299.

NASRIL B.S. (2003): Continuous multi-phase feeding of broiler chickens. A Diddertation, Texas. 
REZAEI M., TEIMOURI A., POURREZA J., SAYYAHZADEH H., WALDROUP P.W. (2006): Effect of diet dilution in the starter period on performance and carcass characteristics of broiler chicks. Journal Central European Agriculture, 7, 1, 63-70.

SALEH E.A., WARKINS S.E., WALDROUP W.P. (1996): Changing time of feeding starter, grower, and finisher diets for broilers.1. Birds grown to $1 \mathrm{~kg}$. J. Appl. Poult. Res., 5, 269-275.

TEIMOURI A., RAZAEI M., POURREZA J., SAYYAHZADEHH H., WALDROUP P.W. (2005): Effect of diet Dilution on the starter Period on performance and Carcass Characteristics of Broiler Chichs. International Journal of poultry Science, 4, 12, 1006-1011.

WARREN W.A., EMMERT J.L (2000): Efficacy of phase-feeding in supporting growth performance of broiler chuck during the starter and finisher phases. Poult. Sci., 79, 764-770.

Received 03 February 2010; accepted for publication 22 February 2010 